\title{
Kenali Gejala Dan Perilaku Beresiko Hepatitis di Puskesmas Simpang Tiga Pekanbaru
}

\author{
Yuyun Priwahyuni*, Christine Vita Gloria, Agus Alamsyah, Ikhtiyaruddin, \\ Nia Septia Lisa, Ferda Melenina \\ Prodi Kesehatan Masyarakat, STIKes Hang Tuah Pekanbaru \\ email: yuyun.priwahyuni@gmail.com
}

\begin{abstract}
Hepatitis is a liver disorder in the form of inflammation of liver cells. Inflammation is characterized by increased levels of liver enzymes. The increase is caused by impaired liver membrane damage. There are two contributing factors, namely infection and non-infectious factors. Factors causing infection include hepatitis viruses and bacteria. Viral hepatitis is an infectious disease in the form of liver inflammation caused by a virus. Types of viral hepatitis consist of hepatitis A, B, C, D, and E. The PKM counseling method and health education about recognizing the symptoms and behaviors at risk of hepatitis, target community PKM at Simpang Tiga Marpoyan Damai Health Center in Pekanbaru City. The activity was held on Saturday, November 23, 2019. The results of PKM activities were obtained that from 70 people who participated in the activity, $70 \%$ of the people knew and could mention about hepatitis, especially the community was able to recognize the symptoms of hepatitis and risk behaviors that could cause hepatitis. Counseling and health education activities in the form of lectures about identifying symptoms and behaviors at risk of hepatitis are very effective in the community. To related parties such as the DinKes and Puskesmas Simpang Tiga can schedule this activity regularly and conduct health counseling activities well to the public about hepatitis $A, B$, and C.Abstract is written in English and Indonesian (except articles written in English) which contain key issues, research objectives, methods / approaches and research results..
\end{abstract}

Keywords: Virus, Hepatitis A B C, Simpang Tiga Health Center.

\begin{abstract}
Abstrak
Hepatitis adalah kelainan hati berupa peradangan sel hati. Peradangan ditandai dengan peningakatan kadar enzim hati. Peningkatan disebabkan adanya gangguan kerusakan membran hati. Ada dua faktor penyebabnya yaitu faktor infeksi dan faktor noninfeksi. Faktor penyebab infeksi antara lain virus hepatitis dan bakteri. Hepatitis Virus adalah penyakit menular dalam bentuk peradangan hati yang disebabkan oleh virus. Jenis hepatitis virus terdiri atas hepatitis A, $B, C, D$, dan E. Tujuan PKM adalah untuk meningkatkan pengetahuan dan pemahaman masyarakat bagaimana mengenali gejala dan perilaku beresiko hepatitis. Metode PKM penyuluhan dan pendidikan kesehatan tentang kenali gejala dan perilaku beresiko hepatitis, sasaran PKM masyarakat di Puskesmas Simpang Tiga Marpoyan Damai Kota Pekanbaru. Kegiatan dilaksanakan Sabtu 23 November 2019. Hasil kegiatan PKM didapat bahwa dari 70 masyarakat yang mengikuti kegiatan tersebut, $70 \%$ masyarakat mengetahui dan dapat menyebutkan mengenai tentang penyakit hepatitis terutama masyarakat sudah dapat mengenali gejala hepatitis dan perilaku yang beresiko yang dapat menyebabkan penyakit hepatitis. Kegiatan penyuluhan dan pendidikan kesehatan berupa ceramah tentang kenali gejala dan perilaku beresiko hepatitis sangat efektif dilaksanakan pada masyarakat. Kepada pihak terkait seperti DinKes dan Puskesmas Simpang Tiga dapat mengagendakan kegiatan ini secara rutin dan melakukan kegiatan penyuluhan kesehatan dengan baik kepada masyarakat tentang penyakit hepatitis $A, B$, dan $C$.
\end{abstract}

Kata kunci: Virus, Hepatitis A B C, Puskesmas Simpang Tiga 


\section{PENDAHULUAN}

Jumlah kasus penyakit menular di Indonesia masih dalam kategori tinggi. Penyakit menular merupakan penyakit yang ditularkan melalui berbagai media. Penyakit jenis ini merupakan masalah kesehatan yang besar hampir di semua negara berkembang karena angka kesakitan dan kematiannya yang relatif tinggi dalam waktu yang relatif singkat. Salah satu diantara banyaknya penyakit menular yang perlu ditangani adalah penyakit hepatitis. Hepatitis adalah peradangan atau infeksi pada sel-sel hati. Penyebab hepatitis yang paling sering adalah virus yang dapat menyebabkan pembengkakan dan pelunakan hati [1].

Hepatitis A adalah penyakit menular yang disebabkan oleh virus Hepatitis A (HAV) yang bertransmisi HAV melalui fecal-oral, yakni virus masuk ke dalam tubuh ketika seseorang mengonsumsi makanan atau minuman yang terkontaminasi tinja mengandung HAV. Hepatitis A tergolong penyakit menular yang ringan, sehingga dapat sembuh spontan atau sempurna tanpa gejala sisa, serta tidak menyebabkan infeksi kronis. Penderita sebagian besar cenderung mengalami penyembuhan sendiri (self limiting disease) dengan kematian yang sangat sedikit yaitu sekitar 0,10-0,30\%. Hepatitis A sering menyebabkan kejadian luar biasa dalam periode waktu satu hingga dua bulan dengan kecenderungan berulang secara siklik [2].

Penyakit Hepatitis A sering muncul dalam bentuk KLB seperti yang terjadi di beberapa tempat di Indonesia [3].

Penyakit hepatitis kronis dengan berbagai etiologi terutama akibat infeksi hepatitis B Virus (HBV) dan hepatitis C Virus (HCV) menjadi penyebab utama meningkatnya angka kesakitan dan angka kematian diseluruh dunia. Penyakit hepatitis kronis merupakan suatu penyakit nekroinflamasi hati yang berlanjut dan tanpa perbaikan paling sedikit selama 6 bulan, yang melibatkan proses destruksi yang progresif dan regenerasi dari parenkim hati yang pada akhirnya akan menuju fibrosis, sirosis hingga karsinoma hepatoseluler (KHS), dimana keduanya dapat menyebabkan kematian akibat gagal hati [4].

Penyebaran penyakit Hepatitis B sangat mengerikan. World Health Organization (WHO) tahun 2002 memperkirakan bahwa satu biliun individu yang hidup telah terinfeksi Hepatitis B, sehingga lebih dari 200 juta orang di seluruh dunia terinfeksi, dan 12 juta kematian setiap tahun dikaitkan dengan HBV. Pada Tahun 2008 jumlah orang terinfeksi HBV sebanyak 2 miliar, dan 350 juta orang berlanjut menjadi pasien dengan infeksi Hepatitis B kronik [5].

Berdasarkan hasil observasi dan survei data di lapangan yaitu di Puskesmas Simpang Tiga Pekanbaru terdapat pada bulan maret dan bulan april tahun 2019 terdapat usia 20-44 tahun ada 1 orang yang terkena penyakit hepatitis yang berjenis kelamin wanita di setiap bulan maret dan april.

Melaksanakan Pengabdian

Masyarakat Penyuluhan Kesehatan Kenali Gejala dan Perilaku Beresiko Hepatitis pada masyarakat di Puskesmas Simpang Tiga Kecamatan Marpoyan Damai Kota Pekanbaru merupakan salah satu bentuk kegiatan dalam meningkatkan pengetahuan dan pemahaman masyarakat dalam mengetahui penyakit hepatitis dan mengenali gejalanya, serta mengetahui perilaku beresiko dari hepatitis, dan mencegah tertularnya penyakit hepatitis tersebut.

\section{METODE PENGABDIAN}

Metode yang akan digunakan dalam pelaksanaan ini adalah bentuk pengabdian kepada masyarakat berupa 
penyuluhan dan pendidikan kesehatan. Adapun tahapan pelaksanaan kegiatan yang dilakukan meliputi tahapan persiapan, tahapan pelaksanaan dan monitoring evaluasi. Tahap persiapan meliputi pertemuan dengan instansi tempat pengabdian masyarakat yaitu di Puskesmas Simpang Tiga Pekanbaru dan rencana kegiatan apa yang dilakukan. Tahap pelaksanaan meliputi pelaksanaan kegiatan pengabdian masyarakat. Tahap monitoring evaluasi meliputi evaluasi hasil dari kegiatan pengabdian masyarakat berupa penyuluhan dan pendidikan kesehatan kenali gejala dan perilaku beresiko hepatitis.

\section{HASIL DAN PEMBAHASAN}

Kegiatan Pengabdian Masyarakat dilaksanakan di Puskesmas Simpang Tiga Kecamatan Marpoyan Damai Kota Pekanbaru. Kegiatan di ikuti oleh masyarakat yang berjumlah 70 orang, kegiatan dilaksanakan pada hari Sabtu tanggal 23 November 2019 yang dimulai pukul 09.00 WIB sampai dengan selesai.

Bentuk pelaksanaan kegiatan pengabdian yang dilaksanakan adalah penyuluhan dan pendidikan kesehatan berupa ceramah tentang kenali gejala dan perilaku beresiko hepatitis.

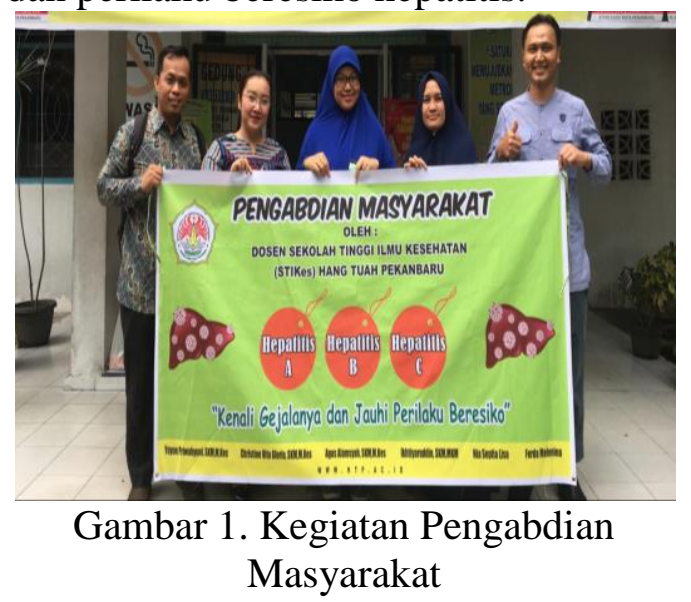

Penyuluhan dan pendidikan kesehatan dilakukan oleh para pengabdi dan dibantu oleh para mahasiswa/i STIKes Hang Tuah Pekanbaru Semester 3. Sebelum para peserta yakni masyarakat tersebut diberikan penjelasan tentang hepatitis, sejumlah masyarakat diberikan pertanyaan terlebih dahulu untuk mengetahui pengetahuan masyarakat terkait mengenali gejala dan perilaku beresiko hepatitis. Dari hasil tersebut dapat terlihat bahwa dari 70 masyarakat yang mengikuti kegiatan tersebut, hanya $20 \%$ masyarakat yang mengetahui apa perilaku yang beresiko penyebab hepatitis.

Setelah para pengabdi menyampaikan materi pendidikan kesehatan tentang hepatitis, sejumlah masyarakat diberikan pertanyaan kembali mengenai penyakit hepatitis. Hasil yang didapat bahwa dari 70 masyarakat yang mengikuti kegiatan tersebut, $70 \%$ masyarakat mengetahui dan dapat menyebutkan mengenai tentang penyakit hepatitis terutama masyarakat sudah dapat mengenali gejala hepatitis dan perilaku yang beresiko yang dapat menyebabkan penyakit hepatitis.

Masyarakat perlu mengetahui dan mengenali gejala dari hepatitis A, B dan C. Perilaku beresiko yang harus diketahui masyarakat dari penyakit hepatitis A, B, dan $\mathrm{C}$ adalah yaitu penularan penyakit terjadi karena kontak dalan lingkungan keluarga dan kontak seksual dengan penderita akut, dan juga muncul secara sporadis di tempat-tempat penitipan anak usia sebaya, menyerang wisatawan yang bepergian ke negara dimana penyakit tersebut endemis, menyerang si pengguna suntikan pecandu obat terlarang dan pria homoseksual.

Didaerah dengan sanitasi lingkungan yang rendah, infeksi umumnya terjadi pada usia yang sangat muda. Penularan selama kehamilan dan pada masa bayi dan anak-anak. Masyarakat perlu mengetahui dan menerapkan perlindungan khusus pada dirinya sendiri dalam mencegah penyakit 
hepatitis, dimana perlindungan khusus adalah upaya yang dilakukan agar masyarakat dapat terlindungi dari penularan Hepatitis Virus.

Promosi kesehatan adalah upaya untuk meningkatkan pengetahuan, perubahan perilaku, keterampilan, dan komitmen dalam penyelenggaraan penanggulangan Hepatitis Virus, sehingga masyarakat memahami Hepatitis Virus secara baik dan benar dan mampu untuk mengakses terhadap upaya perlindungan khusus, pemberian imunisasi, mengetahui dan memahami cara pencegahan untuk dirinya, orang lain, dan masyarakat luas, serta mencegah terjadinya stigma dan diskriminasi terhadap orang dengan Hepatitis Virus.

Pelaksanaan pengabdian masyarakat Penyuluhan Kesehatan Kenali Gejala dan Perilaku Beresiko Hepatitis pada masyarakat di Puskesmas Simpang Tiga Kecamatan Marpoyan Damai Kota Pekanbaru merupakan salah satu bentuk kegiatan dalam meningkatkan pengetahuan dan pemahaman masyarakat dalam mengetahui penyakit hepatitis dan mengenali gejalanya, serta mengetahui perilaku beresiko dari hepatitis, dan mencegah tertularnya penyakit hepatitis tersebut.

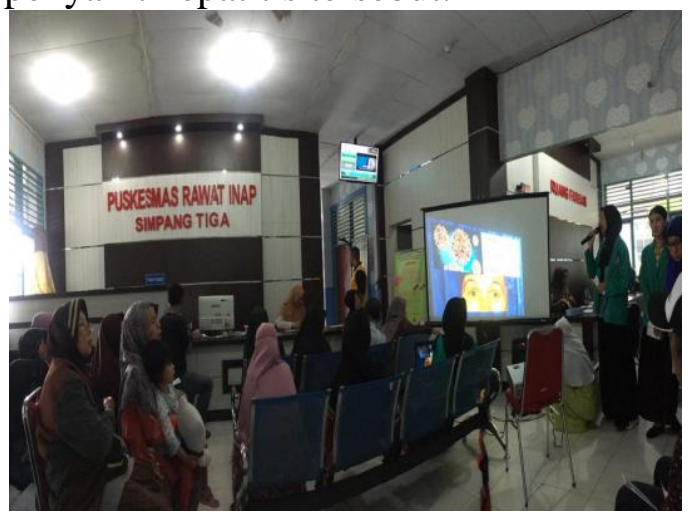

Gambar 2. Penyuluhan Kesehatan tentang Hepatitis

\section{SIMPULAN}

Hasil yang dicapai melalui kegiatan Pengabdian Masyarakat tentang Kenali
Gejala dan Perilaku Beresiko Hepatitis adalah sebagai berikut :

1. Masyarakat mendapatkan
pengetahuan baru tentang bagaimana mengenali gejala penyakit hepatitis dan perilaku beresiko, serta pencegahannya dengan diadakannya kegiatan tersebut.

2. Tersedia media promosi kesehatan berupa spanduk, banner, leaflet, dan power point.

\section{UCAPAN TERIMA KASIH}

Ucapan terimakasih kami sampaikan kepada Pusat Penelitian dan Pengabdian Masyarakat STIKes Hang Tuah Pekanbaru sebagai pemberi dana dalam kegiatan pengabdian masyarakat yang telah dilaksanakan pada bulan November 2019. Serta ucapan terimakasih kepada Puskesmas Simpang Tiga Pekanbaru yang telah memberikan kesempatan dalam pelaksanaan pengabdian masyarakat.

\section{DAFTAR PUSTAKA}

[1] R. Misna, U. Zein, and B. Suroyo, "Faktor Risiko Hepatitis B Pada Pasien di RSUD. Dr. Pirngadi Medan," J. Kesehat. Glob., vol. 1, no. 1, pp. 37-44, 2018.

[2] F. B. Harisma, F. Syahrul, T. Mubawadi, and Y. A. Mirasa, "Analisis Kejadian Luar Biasa Hepatitis A Di SMA X Kabupaten Lamongan Tahun 2018," J. Berk. Epidemiol., vol. 6, no. 2, pp. 112121, 2018.

[3] M. Y. Alamudi, M. I. Hadi, and M. L. F. Kumalasari, "HbsAg Screening In Teenagers In Surabaya By Using Rapid Test Skrinning HbsAg Pada Remaja Di Surabaya Dengan Menggunakan Rapid Test," J. Kesehat. Masy., vol. 9, no. 1, pp. 30-33, 2018. 
ISSN : 2550-0198

[4] R. D. Wahyuni, “Analisis Derajat Fibrosis Hati Dengan Fibroscan, Indeks FIB4, King's Score dan Apri Score Pada Penyakit Hepatitis Kronis," J. Kesehat. Tadulako, vol. 2, no. 2, pp. 1-71, 2016.

[5] R. Aini and J. Susiloningsih, "Faktor Resiko yang Berhubungan dengan Kejadian Hepatitis B pada Pondok Pesantren Putri Ibnul Qoyyim Yogyakarta," Sains Med., vol. 5, no. 1, pp. 30-33, 2013. 